Vol. 6 (1997): 207-217.

\title{
Farmers' exposure to dusts and gases in modern Finnish cubicle cow houses
}

\author{
Kyösti Louhelainen, Juhani Kangas, Marjut Reiman \\ Kuopio Regional Institute of Occupational Health, PO Box 93, FIN-70701 Kuopio, Finland, \\ e-mail: kyosti.louhelainen@occuphealth.fi
}

Pentti Kalliokoski

University of Kuopio, Department of Environmental Sciences, PO Box 1627, FIN-70211 Kuopio, Finland

The occurrence of airborne dust, gases, microbes, endotoxin and bovine epithelial antigens (BEA, BDA20) was studied in 26 modern, mainly cubicle, cow houses. Air samples of total dust, total spores, endotoxin and bovine epithelial allergens were collected on membrane filters with portable or piston pumps and analyzed with appropriate methods. Concentrations of gases (ammonia, carbon dioxide, hydrogen sulfide) were measured with diffusion tubes. Airborne viable spores were collected with a cascade impactor on five selective culture media for the identification of xerophilic, mesophilic and thermotolerant fungi and thermophilic actinomycetes.

The geometric mean concentrations of total dust, BEA and BDA20 were $0.2-1.9 \mathrm{mg} / \mathrm{m}^{3}, 5.2-$ $9.7 \mu \mathrm{g} / \mathrm{m}^{3}$ and $50-260 \mathrm{ng} / \mathrm{m}^{3}$, respectively. The mean concentrations of ammonia and carbon dioxide were between $2.8-15 \mathrm{ppm}$ and $2200-3200 \mathrm{ppm}$, respectively. The geometric mean of endotoxins was $19 \mathrm{ng} / \mathrm{m}^{3}$ and the concentrations of fungi were at the $10^{1}-10^{3} \mathrm{cfu} / \mathrm{m}^{3}$ level.

In general, the variation in concentrations of total dust, viable fungi and endotoxin was large. The concentrations of total dust and fungi were lower than in earlier studies. Thus new cubicle houses provide a better working environment with regard to airborne hazards than the traditional cow houses.

Key words: agriculture, airborne health hazards, allergens, micro-organisms

\section{Introduction}

Farm workers are exposed to a variety of agents that can cause injury by inhalation. Epidemiological studies indicate a high prevalence of respiratory symptoms or diseases among farmers

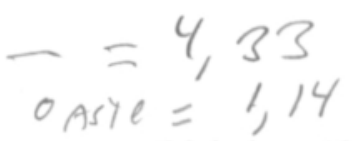

(Malmberg 1990, Terho et al. 1987, Tammilehto et al. 1994, Donham 1993). Symptoms of chronic bronchitis and farmer's lung are still the most common respiratory complaints among dairy farmers (Tammilehto et al. 1994). In Finland, during recent years the dominant etiologic factor for occupational respiratory diseases among 


\section{AGRICULTURAL AND FOOD SCIENCE IN FINLAND}

\section{Louhelainen, K. et al. Farmers' exposure to dusts and gases in cubicles}

farmers has been cow dander, but microbial exposure also has caused hundreds of cases of farmer's lung (Karjalainen et al. 1996, 1997, Kauppinen et al. 1994, 1995).

The mean levels of total dust in cow houses have been low (range from 0.7 to $1.5 \mathrm{mg} / \mathrm{m}^{3}$ ) (Louhelainen et al. 1987a, Virtanen et al. 1986, Virtanen et al. 1988) related to swineries (Louhelainen et al. 1987b, Gustafsson 1988, Donham et al. 1995). Thus other factors which are constituents of dust explain the etiology of respiratory diseases in the farming population. The airborne concentrations and serological studies of bovine epithelial antigen (BEA) and $20 \mathrm{kD}$ bovine dander antigen (BDA20) have been reported mainly by Finnish researchers (Virtanen et al. 1986, Virtanen et al. 1988, Virtanen et al. 1992, Ylönen et al. 1990, Ylönen et al. 1994).

Several studies have concluded that the main sources of microbial dust in agriculture are hay, straw and grain (Kotimaa et al. 1987, Kotimaa 1990, Kotimaa et al. 1991). Straw samples liberate significantly larger numbers of spores than hay and grain do (Kotimaa 1990). Thermoactinomyces vulgaris has been the predominant microbe from straw and Aspergillus umbrosus from hay and grain. On farms where fodder was dried artificially the concentration of thermophilic actinomycetes was lower than on farms with a traditional storage system (Dalphin et al. 1991). Malmberg and coworkers concluded that allergic alveolitis was associated with high levels of exposure to mold spores on most weekdays for weeks at a time and that ODTS (organic dust toxic syndrome) was associated with extreme exposure on a single day (Malmberg et al. 1993). In agriculture, endotoxins can be found in various materials and environments (Olenchock et al. 1990, Liesivuori et al. 1994).

Ammonia is the most harmful of the gases causing respiratory symptoms normally found in animal houses (Kangas et al. 1987, Donham 1991, Donham et al. 1995). In cow houses, the lowest concentrations of airborne ammonia have been found in facilities equipped with a low exhaust system of ventilation through the manure channels (Gustafsson 1988, Linnainmaa et al. 1993).

The objective of this study was to investigate airborne health hazards during the working period in 26 modern, mainly cubicle, cow houses. The factors measured were total dust, bovine epithelial and dander allergens, microbial dust, endotoxins, ammonia, carbon dioxide and hydrogen sulfide.

\section{Material and methods}

A total of 26 farms were included in this study. They were chosen among about 80 farms provided by agricultural extension services. The main criteria for including a farm in the study were that the cow houses had to be new, the number of milking cows high (20-30) and it had to be a family farm. The cow houses were new, less than five years old; the mean year of construction or complete renovation was 1991, range 1989-93. Each farm was run by two persons and the mean number of milking cows was 22 (range 17-40). Twenty-three farms had cubicle houses (loose-housing barns), two had traditional tie stall barns and one had a cold cubicle barn. The cold cubicle (cold loose-housing barn) is the latest method of barn construction, but not yet common in Finland. The cow department is uninsulated and equipped with wooden walls and roof. The ventilation is natural with openings in the roof. The milking parlor is a separate warm and insulated room beside the cold barn. All warm barns had a mechanical system of ventilation, but only one farm had a detailed design for ventilation. The farms were situated in middle and southern Finland.

All except two of the barns had an automatic feeding system for milking cows, but the heifers had to be fed manually. The normal working tasks included cleaning the feeding table anc feeding the cows with forage, fodder grain and dry hay. Hay for fodder was used on 23 of the 


\section{AGRICULTURAL AND FOOD SCIENCE IN FINLAND}

Vol. 6 (1997): 207-217.

26 farms; straw was used for bedding on 6 farms, wood shavings on 13 farms; and seven of the farms did not use bedding at all.

Measurements were made during winter and early autumn between 1994-1995 in each cow house. The indoor temperatures and relative humidity measured in the barn varied from 7 to $17^{\circ} \mathrm{C}$ (mean $12.7^{\circ} \mathrm{C}$ ) and 55 to $95 \%$ (mean $87 \%$ ), respectively. At the time of measurement the temperature in the cold loose barn was $-6^{\circ} \mathrm{C}$. The outdoor temperature was from +2 to $-20^{\circ} \mathrm{C}$ during farm visits.

The total dust was sampled gravimetrically according to the Finnish standard method (SFS $3860)$. For results below the limit of detection $\left(0.1 \mathrm{mg} / \mathrm{m}^{3}\right.$ for area sampling and $0.5 \mathrm{mg} / \mathrm{m}^{3}$ for breathing zone sampling according to the standard) half of the limit of detection has been used for interpreting the results (CEN 1995). Dust samples were collected on membrane filters (Millipore, USA) mounted in open-faced threepiece cassettes (Millipore, USA). Personal sampling was done at air flow rates of $2-2.5 \mathrm{~L} / \mathrm{min}$ (SKC, USA) and stationary sampling at flow rates of 20-25 L/min (Piston pump, Finland). Samples were taken during the whole working period, and therefore the sampling time varied from 1.5 to 3.5 hours. The sampling sites for stationary sampling in cubicle houses were located in the milking parlor and in the feeding aisle, and in tied barns they were located in the feeding and manure aisles. The purpose of the stationary samples was to evaluate spreading of the dust. For personal sampling 1-2 samples were taken. The pumps were weekly calibrated with a calibrator (Gilian, USA) and the pumps were checked visually during the measurements.

Samples for bovine epithelial antigen and specific bovine dander antigen were collected in the same way as samples for total dust. After sampling the filters were frozen at $-20^{\circ} \mathrm{C}$ until analyzed. The samples were analyzed for BEA by a immunochemical method described by Virtanen et al. (1992) and for BDA20 with two-site immunometric assay described in detail by Ylönen et al. (1994).
Viable fungal spores were sampled with a sixstage Andersen impactor (Model 10-800, Andersen Inc., USA). Sampling volume was 50 to 100 liters. The culture media and incubation temperatures and times for analysis of viable spores were; xerophilic fungi on $\mathrm{NaCl}$ malt extract agar or on Dichloran Glycerol 18 (DG18) agar at $+20^{\circ} \mathrm{C}$ for 7 days, mesophilic fungi on Hagem agar at $+20^{\circ} \mathrm{C}$ for 7 days, thermotolerant fungi on Hagem agar at $+40^{\circ} \mathrm{C}$ for $3-5$ days, thermophilic actinomycetes on half-strength nutrient agar at $+55^{\circ} \mathrm{C}$ for 3 days. Xerophilic fungi are low-moisture fungi found for example in hay. The optimum temperature range for mesophilic fungi is $20-25^{\circ} \mathrm{C}$, whereas thermotolerant fungi are heat-tolerant up to $45^{\circ} \mathrm{C}$ and thermophilic fungi can grow at temperatures up to $60^{\circ} \mathrm{C}$ (Dix $\&$ Webster 1995). Viable spore counts were calculated as colony forming units per cubic meter of air $\left(\mathrm{cfu} / \mathrm{m}^{3}\right)$, and the fungal or bacterial group was identified with a light microscope. Three types of samples were taken, one background sample one hour before work, one during milking when hay, forage and fodder grain were also delivered to cows and heifers, and the third one two hours after the work was finished. The concentrations of total spores were determined by the CAMNEA method described by Palmgren et al. (1986).

Endotoxin sampling and analysis is described in detail by Laitinen et al. (1994). One nanogram of endotoxin standard from Esherichia coli 0111:B4 corresponds to 12 endotoxin units.

Concentrations of airborne ammonia, carbon dioxide, and occasionally also hydrogen sulfide were measured with passive diffusion tubes (ammonia 20/a-D, carbon dioxide 500/a-D, hydrogen sulfide 10/a-D, Draeger, Germany) from feeding aisles or in the case in tied barns in manure aisle and in milking parlor. Sampling time for gases was the whole working period of the farmers, 1.5 to $3.5 \mathrm{~h}$.

When the results were interpreted, the milking parlors were divided into 1) open-parlors open to the barn, separated only by a fence about $2 \mathrm{~m}$ high and 4-5 m long and 2) closed parlors totally separated from the rest of the barn. 


\section{AGRICULTURAL AND FOOD SCIENCE IN FINLAND}

\section{Louhelainen, $K$. et al. Farmers' exposure to dusts and gases in cubicles}

\section{Data analysis}

Most of the statistical analyses were performed with log-transformed data, because the data was not normally distributed. When the GM (geometric mean) values were calculated for fungi and actinomycetes, 1 was added to each result because the results included zero values. The statistical significance of differences between microbial concentrations measured in three consecutive periods (before work, during milking and $2 \mathrm{~h}$ after milking) were tested by repeated measures analysis of variance (ANOVA) for normal distribution and Friedman rank ANOVA for nonnormal distribution. The differences in the concentrations of total dust, endotoxin, bovine epithelial antigens, and gases between the milking parlors and stationary and personal sampling sites were examined with the t-test for normal distribution or Mann-Whitney U-test for nonnormal distribution. The correlations between the variables were tested with Pearson product moment correlation coefficient or with Spearman production moment regression.

\section{Results}

The geometric mean concentrations of total dust did not exceed the OEL (Occupational Exposure Level) of $5 \mathrm{mg} / \mathrm{m}^{3}$ for organic dust (Työministeriö 1996). Seven samples from a total 52 samples in area measurements and 15 samples from a total 45 personal samples were under the respective detection limits. There were no statistical differences in the total dust concentrations between sampling sites or between persons doing feeding and milking work (Table 1). The personal concentrations of total dust were 2 to 3 times higher than the area concentrations (t-test, $\mathrm{p}<0.001)$. The highest personal total dust concentration $\left(14.5 \mathrm{mg} / \mathrm{m}^{3}\right)$ was measured during feed delivery in a barn where the farmer had to take feed to the calves from a silo with a showel.
The GM concentrations of BEA were at the same level in area sites and breathing zones in both tied houses and cubicle houses (Table 2). Concentrations of BDA20 antigen were 2 to 3 times higher in the breathing zone samples than in the area site samples in cubicles (t-test, $\mathrm{p}<0.001$ ) (Table 2). However, no correlations were found between concentrations of total dust and BEA or BDA20 in open- or closed-type parlors either in the breathing zone samples or at stationary site samples.

In all 26 barns the GM of endotoxin concentration was $19 \mathrm{ng} / \mathrm{m}^{3}$. The endotoxin concentration was $5.5 \mathrm{ng} / \mathrm{m}^{3}$ in the cold cow barn, and in other barns the GMs varied from 16 to $27 \mathrm{ng} / \mathrm{m}^{3}$.

The concentrations of viable fungi varied strongly during different sampling periods (Table 3 ). For every group of microorganisms, in the closed parlors, the concentrations were $2-3$ times higher during milking than during other measurement periods, but in the open parlors, in only with thermophilic actinomycetes. In addition, the concentrations of microorganisms in the cold barn parlor were at about the same level as in other parlors. Statistical differences (ANOVA or Friedman rank ANOVA, p $<0.05$ ) between measuring periods were found with both xerophilic (NaCl-Malt and DG18), mesophilic fungi and thermophilic actinomycetes in closed -type parlors, but not with any group of fungi or actinomycetes in open-type parlors. In the tied barns during milking, the geometric means of all microorganisms except thermophilic actinomycetes were about ten times higher than concentrations measured from all other cow houses. This difference was not noticed for before work or after work measurements.

The mean total spore count during milking was $1.2 \times 10^{5}$ spores $/ \mathrm{m}^{3}$ (Table 3 ). The viable fungal spores of xerophilic, mesophilic, thermotolerant fungi and thermophilic actinomycetes consisted of about $1-77 \%$ of the total spores measured during milking. There was no correlation between the concentration of viable spores from any group of fungi and the total spore count. The prevalence of viable fungal groups or gen- 
Vol. 6 (1997): 207-217.

Table 1. Concentrations of total dust during indoor farm work, $\mathrm{mg} / \mathrm{m}^{3}$. ( $\mathrm{n}=$ number of samples, $\mathrm{AM}=$ arithmetic mean, $\mathrm{GM}=$ geometric mean, $\mathrm{s}=$ stationary sampling site, $\mathrm{bz}=$ breathing zone sampling)

\begin{tabular}{|c|c|c|c|c|c|c|c|c|c|c|c|c|c|c|c|c|}
\hline & \multicolumn{4}{|c|}{ Feeding aisle, s } & \multicolumn{4}{|c|}{ Milking parlor, s } & \multicolumn{4}{|c|}{ Milking, bz } & \multicolumn{4}{|c|}{ Feeding, bz } \\
\hline & $\mathrm{n}$ & $\mathrm{AM}$ & GM & range & $\mathbf{n}$ & $\mathrm{AM}$ & GM & range & $\mathbf{n}$ & $\mathrm{AM}$ & GM & range & & $\mathrm{AM}$ & GM & range \\
\hline cold barn & 1 & 0.7 & & & 1 & 0.1 & & & 1 & 0.3 & & & 1 & 1.8 & & \\
\hline tied barn & 2 & 0.2 & 0.2 & $0.2-0.3$ & 2 & 0.2 & 0.2 & $0.2-0.3$ & 2 & 1.0 & 0.8 & $0.25-1.8$ & 2 & 0.3 & 0.3 & $0.25-0.3$ \\
\hline cubicle & 23 & 0.8 & 0.3 & $0.05-11.7$ & 23 & 0.3 & 0.2 & $0.05-1.2$ & 17 & 1.1 & 0.6 & $0.25-4.5$ & 23 & 1.9 & 0.8 & $0.25-4.5$ \\
\hline closed & 12 & 1.2 & 0.3 & $0.05-11.7$ & 12 & 0.4 & 0.2 & $0.05-1.2$ & 9 & 1.3 & 0.7 & $0.25-1.5$ & 12 & 2.5 & 0.9 & $0.25-4.5$ \\
\hline open & 11 & 0.4 & 0.2 & $0.05-1.3$ & 11 & 0.2 & 0.1 & $0.05-0.4$ & 8 & 0.8 & 0.5 & $0.25-4.5$ & 11 & 0.8 & 0.7 & $0.25-2.2$ \\
\hline
\end{tabular}

Table 2. Concentrations of BEA (bovine epithelial antigen) and BDA20 (bovine dander antigen) in cow houses. ( $\mathrm{n}=$ number of samples, $\mathrm{AM}=$ arithmetic mean, $\mathrm{GM}=$ geometric mean, $\mathrm{s}=$ stationary sampling site, $\mathrm{bz}=\mathrm{breathing} \mathrm{zone}$ sampling)

\begin{tabular}{|c|c|c|c|c|c|c|c|c|c|c|c|c|c|c|c|}
\hline & \multicolumn{4}{|c|}{ Feeding aisle, s } & \multicolumn{4}{|c|}{ Milking parlor, s } & \multicolumn{4}{|c|}{ Milking, bz } & \multicolumn{3}{|c|}{ Feeding, bz } \\
\hline & $\mathrm{n}$ & $\mathrm{AM}$ & GM & range & $\mathbf{n}$ & $\mathrm{AM}$ & GM & range & $\mathrm{n}$ & $\mathrm{AM}$ & GM & range & n AM & GM & range \\
\hline \multicolumn{16}{|c|}{$B E A, \mu g / m^{3}$} \\
\hline cold barn & 1 & 2.8 & & & 1 & 1.3 & & & 1 & 0.9 & & & 110.0 & & \\
\hline tied barn & 2 & 10.6 & 7.3 & $2.9-18.3$ & 2 & 5.4 & 5.2 & $3.8-7.0$ & 2 & 6.5 & 4.6 & $1.1-18.4$ & 223.4 & 9.7 & $2.1-44.8$ \\
\hline cubicle & 23 & 9.2 & 6.1 & $1.3-35.5$ & 22 & 8.0 & 5.3 & $1.4-25.8$ & 18 & 8.6 & 5.6 & $1.4-28.4$ & 2112.9 & 8.6 & $1.7-43.2$ \\
\hline \multicolumn{16}{|c|}{$B D A 20, n g / m^{3}$} \\
\hline cold barn & 1 & 40 & & & 1 & 44 & & & 1 & 90 & & & 1310 & & \\
\hline tied barn & 2 & 50 & 50 & $43-62$ & 2 & 25 & 25 & 24-26 & 2 & 210 & 200 & $140-270$ & 2210 & 200 & $150-270$ \\
\hline cubicle & 23 & 124 & 85 & $12-320$ & 22 & 99 & 76 & $21-450$ & 18 & 240 & 200 & $63-550$ & 21320 & 260 & $60-700$ \\
\hline
\end{tabular}

era is presented in Table 4. The most prevalent fungus was Aspergillus, followed by Cladosporium, Paecilomyces, Penicillium, and Wallemia sebi. The most abundant species of thermoactinomycetes were Thermoactinomyces candidus and $T$. vulgaris. In addition, many yeasts were found on mesophilic media and on both types of xerophilic culture media.

Hydrogen sulfide was not detected in any of the cow houses. In two tied barns, the mean concentration of ammonia was $7 \mathrm{ppm}$ in the feeding aisle and $11 \mathrm{ppm}$ in the manure aisle. In the cold loose barn, the concentration of ammonia was under the limit of detection at both sampling sites. The concentrations of ammonia measured in all 26 cow houses were significantly lower in milking parlors or aisles than in feeding aisles (Mann-Whitney U-test, $\mathrm{p}<0.05$ ). The mean concentrations of ammonia also differed between open and closed parlors in cubicle houses (MannWhitney U-test, p<0.05) (Table 5). The ammonia concentration was significantly lower (t-test, $\mathrm{p}<0.001)$ in closed parlors than in open parlors. The present OEL of $25 \mathrm{ppm}$ was exceeded in only one cow house.

In all 26 cow houses the mean concentrations of carbon dioxide in feeding aisles and milking parlors or aisles were $2970 \mathrm{ppm}$ and $2630 \mathrm{ppm}$, 


\section{AGRICULTURAL AND FOOD SCIENCE IN FINLAND}

\section{Louhelainen, K. et al. Farmers' exposure to dusts and gases in cubicles}

Table 3. Concentrations of viable and total fungi in cow houses.

\begin{tabular}{|c|c|c|c|}
\hline \multirow{2}{*}{$\begin{array}{l}\text { Sampling phase/ } \\
\text { fungal group }\end{array}$} & \multicolumn{3}{|c|}{ Spore concentration $\left(\mathrm{cfu} / \mathrm{m}^{3}\right.$, spores $\left./ \mathrm{m}^{3}\right)$} \\
\hline & $\begin{array}{c}\text { Number of } \\
\text { samples }\end{array}$ & GM & Range \\
\hline \multicolumn{4}{|l|}{ Before work } \\
\hline Xerophilic, $\mathrm{NaCl}-\mathrm{Malt}$ & 26 & $1.510^{3}$ & $110-7.710^{4}$ \\
\hline Xerophilic, DG18 & 26 & $2.510^{3}$ & $220-1.110^{5}$ \\
\hline Mesophilic & 26 & $1.410^{3}$ & $80-1.210^{5}$ \\
\hline Thermotolerant & 26 & $1.210^{1}$ & $1-1.110^{5}$ \\
\hline Thermophilic & 26 & $9.310^{\circ}$ & $1-4.010^{3}$ \\
\hline \multicolumn{4}{|l|}{ During milking } \\
\hline Xerophilic, $\mathrm{NaCl}-\mathrm{Malt}$ & 26 & $4.110^{3}$ & $310-9.510^{4}$ \\
\hline Xerophilic, DG18 & 26 & $6.010^{3}$ & $160-9.910^{4}$ \\
\hline Mesophilic & 26 & $3.810^{3}$ & $77-1.510^{5}$ \\
\hline Thermotolerant & 26 & $2.710^{1}$ & $1-9.510^{3}$ \\
\hline Thermophilic & 26 & $2.410^{1}$ & $1-1.810^{4}$ \\
\hline CAMNEA, total spore count & 12 & $1.210^{5}$ & $2.510^{4}-6.310^{5}$ \\
\hline \multicolumn{4}{|l|}{2 h after work } \\
\hline Xerophilic, $\mathrm{NaCl}-\mathrm{Malt}$ & 26 & $1.810^{3}$ & $31-1.210^{5}$ \\
\hline Xerophilic, DG18 & 26 & $3.410^{3}$ & $100-1.210^{5}$ \\
\hline Mesophilic & 26 & $1.810^{3}$ & $20-1.310^{5}$ \\
\hline Thermotolerant & 26 & $1.810^{1}$ & $1-3.010^{4}$ \\
\hline Thermophilic & 26 & $8.410^{\circ}$ & $1-8.610^{3}$ \\
\hline
\end{tabular}

$\mathrm{GM}=$ Geometric mean

respectively. In cubicles, carbon dioxide concentrations did not differ significantly between sites (t-test, $\mathrm{p}<0.1)$ (Table 5). In tied barns the mean concentration of carbon dioxide was $5700 \mathrm{ppm}$ in the feeding aisle and $4600 \mathrm{ppm}$ in the manure aisle. Furthermore, the maximum value reached $6100 \mathrm{ppm}$. Due to the nearly outdoor conditions, in the cold cubicle barn the carbon dioxide concentration was only $900 \mathrm{ppm}$ in the animal department and $1600 \mathrm{ppm}$ in the milking parlor.

Table 4. Prevalence of fungi and actinomycetes in air samples (\%) collected from cow houses

\begin{tabular}{|c|c|c|c|c|}
\hline $\begin{array}{l}\text { Xerophilic } \\
\text { fungi, }(\mathrm{NaCl})\end{array}$ & $\begin{array}{l}\text { Xerophilic } \\
\text { fungi, (DG-18) }\end{array}$ & Mesophilic fungi & $\begin{array}{l}\text { Thermotolerant } \\
\text { fungi }\end{array}$ & $\begin{array}{l}\text { Thermophilic } \\
\text { actinomycetes }\end{array}$ \\
\hline Aspergillus $100 \%$ & Aspergillus $100 \%$ & Aspergillus $98 \%$ & Aspergillus 53\% & $\begin{array}{l}\text { Th. candidus } \\
24 \%\end{array}$ \\
\hline Cladosporium $38 \%$ & Cladosporium $39 \%$ & Cladosporium $16 \%$ & Acremonium $1 \%$ & $\begin{array}{l}\text { Th. vulgaris } \\
32 \%\end{array}$ \\
\hline Paecilomyces $22 \%$ & Paecilomyces $43 \%$ & Paecilomyces $28 \%$ & Paecilomyces 5\% & \\
\hline Penicillium 26\% & Penicillium $85 \%$ & Penicillium 68\% & Penicillium 7\% & \\
\hline \multirow{4}{*}{$\begin{array}{l}\text { Wallemia sebi } 2 \% \\
\text { yeasts } 60 \% \\
\text { sterile } 9 \%\end{array}$} & Wallemia sebi $57 \%$ & Rhizopus $6 \%$ & Trichoderma $2 \%$ & \\
\hline & Scopulariopsis 2\% & Hyalodendron 3\% & Thermoascus $6 \%$ & \\
\hline & yeasts $69 \%$ & Trichoderma $2 \%$ & yeasts $11 \%$ & \\
\hline & sterile $14 \%$ & $\begin{array}{l}\text { Monilia } 1 \% \\
\text { yeasts } 66 \% \\
\text { sterile } 10 \%\end{array}$ & sterile $1 \%$ & \\
\hline
\end{tabular}


Vol. 6 (1997): 207-217.

Table 5. Concentrations of ammonia and carbon dioxide in cubicle houses, ppm.

\begin{tabular}{|c|c|c|c|c|c|c|c|}
\hline \multirow{2}{*}{$\begin{array}{l}\text { Gas / } \\
\text { type of milking } \\
\text { parlor }\end{array}$} & \multirow[b]{2}{*}{$\mathrm{n}$} & \multicolumn{3}{|c|}{ Milking parlor } & \multicolumn{3}{|c|}{ Feeding aisle } \\
\hline & & mean & S.D. & range & mean & S.D. & range \\
\hline \multicolumn{8}{|l|}{ Ammonia } \\
\hline closed & 12 & 2.8 & 2.9 & $0-7$ & 9.4 & 3.3 & $3-14$ \\
\hline open & 11 & 11 & 5.3 & $3-19$ & 15 & 10 & $2-38$ \\
\hline all buildings & 23 & 6.4 & 5.5 & $0-19$ & 12 & 7.5 & $2-38$ \\
\hline \multicolumn{8}{|l|}{ Carbon dioxide } \\
\hline closed & 12 & 2200 & 490 & $1400-2900$ & 2700 & 750 & $1800-4000$ \\
\hline open & 11 & 2800 & 700 & $1800-4100$ & 3200 & 820 & $2200-4800$ \\
\hline all buildings & 23 & 2500 & 640 & $1400-4100$ & 2900 & 790 & $1800-4800$ \\
\hline
\end{tabular}

S.D. = standard deviation

\section{Discussion}

The farmers' exposure to the airborne dust in cow houses have decreased compared to our previous studies (Louhelainen et al. 1987a, Virtanen et al. 1986, Virtanen et al. 1988), where the total dust levels ranged from 0.7 to $1.5 \mathrm{mg} / \mathrm{m}^{3}$ in the feeding aisles. Obviously one of reasons for this decrease is the development of feeding techniques in agriculture, in particular, the change from manual feeding of cows to totally automatic feeding systems. The farmers in the present study had to do some manual feeding especially for calves and heifers, and on two occasions also for cows. However, the manual feeding did not effect to the concentrations of total dust in the breathing zone of the farmers on those farms. The threshold value of $2.8 \mathrm{mg} / \mathrm{m}^{3}$ proposed by Donham (1995) as the amount of total dust that will produce adverse respiratory effects was rarely exceeded.

The range of concentration of BEA varied from 1.1. to $44.8 \mu \mathrm{g} / \mathrm{m}^{3}$ at different sampling sites. However, the concentration of BEA was similar at stationary sites and in the breathing zone. The BEA concentrations of the present study were at same level as those measured previously (Virtanen et al. 1988) when arithmetic mean concentrations varied from 5 to $23 \mu \mathrm{g} / \mathrm{m}^{3}$ in the breathing zone and from 5 to $13 \mu \mathrm{g} / \mathrm{m}^{3}$ at stationary sites in five cow houses. The concentrations of BDA20 were from one third to half lower at the stationary sites than in the breathing zones of farmers. The range of concentrations of BDA20 between measuring sites was as large as with BEA. In this study in stationary sites the arithmetic means of concentrations of BDA20 were lower than in the previous study (Ylönen et al. 1994), where concentrations ranged from 266 to $295 \mathrm{ng} / \mathrm{m}^{3}$. Somewhat surprisingly, however, there was no correlation between BEA and BDA20. The exposure of farmers to bovine antigens is at the same level in new cubicle houses as in older cow houses. A few probable reasons can be suggested; mechanical ventilation usually decreases the relative humidity and thereafter increases the secondary dust emission from surfaces, and secondly, although the distance between the cow and the milker is greater in a milking parlor, the allergen particles are small in diameter and are emitted easily. In addition, the larger number of cow and heifers may produce more airborne allergenic material than a few cows in smaller cow houses. Most of the cases of occupational asthma and rhinitis in Finland are caused by cow dander in agricultural work. The concentrations of cow dander are consistent in different studies, and it can be speculated that the present levels of bovine allergens can induce adverse health effects for the farming population. 


\section{AGRICULTURAL AND FOOD SCIENCE IN FINLAND}

Louhelainen, K. et al. Farmers' exposure to dusts and gases in cubicles

The geometric means of endotoxin concentrations ranged from 17 to $27 \mathrm{ng} / \mathrm{m}^{3}$. On one farm the endotoxin concentration was very high, 4830 $\mathrm{ng} / \mathrm{m}^{3}$. On that farm the concentrations of microbial dust were also elevated. Even excluding the highest concentration, the results of this study are still about twice as high as those in an earlier study (16 ng/m $\mathrm{m}^{3}$ of endotoxins) of dairy farms (Liesivuori et al. 1994). However, these concentrations were low compared to other agricultural environments, e.g. swineries or poultry yards (Olenchock et al. 1990, Liesivuori et al. 1994).

The concentrations of viable airborne fungi and actinomycetes measured were at the order of $10^{1}-10^{3} \mathrm{cfu} / \mathrm{m}^{3}$ which is lower than those in previous Finnish studies (Kotimaa et al. 1984, 1987, Pasanen et al. 1989, Hanhela et al. 1995). The concentrations of different microbes were higher, but not in all cases significantly higher, during milking than before work or 2 hours after work. In open parlors, however, the concentrations rose further and the highest levels of microbes were found 2 hours after work. The concentrations of all types of microbes measured were significantly lower in the closed-type milking parlor than in the open-type parlor. The obvious reason for this is the closed space, which prevents air from the cow barn from entering the parlor. The prevalences of the predominant fungi (Aspergillus, Penicillium, Wallemia sebi, Cladosporium and yeasts) were similar to those found in earlier Finnish study (Hanhela et al. 1995). In addition, in this study Paecilomyces was found more frequently. Thermophilic actinomycetes, which have been considered to be causative agents of farmer's lung, were found on only a few occasions and in low concentrations compared with earlier findings on Finnish farms (Kotimaa et al. 1984). No correlation was found between microbial concentrations and the type of methods used to dry and store hay (data not shown). These results may be due to modern farm practices in which there is little use of hay for feed, little use of straw for bedding, or no bedding at all. The worst sources of airborne spores are thus eliminated or their role is clearly less- ened (Pasanen et al. 1989, Kotimaa 1990, Kotimaa et al. 1991, Dalphin et al. 1991).

Concentrations of ammonia were lower in closed-type parlors than in open-type parlors. In addition, ammonia concentrations were lower in milking parlors than in the feeding aisles, and this difference was larger on farms with closedtype parlors. The concentrations of ammonia equaled our previous results (Kangas et al. 1987, Linnainmaa et al. 1993) which ranged from 0.2 to $35 \mathrm{ppm}$. The correlations between ammonia levels in milking parlors and in feeding aisles were significant on all 26 farms, in all cubicle houses and open-type houses (Pearson coefficients between $r=0.69-0.74$, $p<0.01$ ), but in closed-type parlors no such correlation was found. Visual investigation with smoke revealed that in several cubicles the ventilation did not remove airborne gases effectively. For example, the inlet air went directly to the outlet channels without mixing, the heat exchangers were blocked by dust, and the outlet fans were insufficient to remove indoor air. Concentration of ammonia is a function of ventilation efficiency but other factors, such as the shape of inlets and outlets, are also involved (Gustafsson 1998, Linnainmaa et al. 1993). The lowest concentrations of ammonia were found in cowhouses from which air was removed only through the manure channels. The correlation of ventilation rate with the concentration of ammonia has been found to be low (Linnainmaa et al. 1993). The lower concentrations of ammonia in milking parlors compared to feeding aisles can be explained by better ventilation of milking parlors, and in particular, by closed space in the closed type parlors. According to Donham et al. (1995), ammonia in swineries is an environmental predictor of decrease in pulmonary function, namely decreased $\mathrm{FEV}_{1}$ (forced expiratory volume in one second) at the level of $7.5 \mathrm{ppm}$ or more. That threshold is only one-fourth of the present OEL ( $25 \mathrm{ppm}$ ) of ammonia. However, this finding is difficult to apply to cow houses because of different exposure patterns, e.g. low concentrations of dust compared to the swineries. 


\section{AGRICULTURAL AND FOOD SCIENCE IN FINLAND}

Vol. 6 (1997): 207-217.

All concentrations of carbon dioxide, except one, were lower than the OEL of $5000 \mathrm{ppm}$. However, the limit recommended by the Ministry of Agriculture and Forestry (3000 ppm) was occasionally exceeded in feeding aisles and also in open-type milking parlors in cubicles. In our previous studies the mean levels of carbon dioxide in tie stalls have been about $1500 \mathrm{ppm}$ and 3100 ppm (Kangas et al. 1987, Linnainmaa et al. 1993). The correlation between carbon dioxide levels in milking parlors and in feeding aisles was significant in all houses and also in openand closed-type parlors (Pearson coefficient between $r=0.80-0.86, p<0.01)$. Donham (1991) proposed that carbon dioxide would be a good substitute indicator of the relative amounts of ammonia, bacteria, endotoxins, and total microbes in swineries. In this study no such correlations were found except between carbon dioxide and ammonia in all 23 cubicle houses and in open-type barns. The correlation between carbon dioxide and ammonia in feeding aisles was less significant (Pearson coefficient $r=0.44$, $\mathrm{p}<0.05$ ) in all cow houses than in cubicle barns (Pearson coefficient $\mathrm{r}=0.55, \mathrm{p}<0.01$ ). In milking parlors or aisles there was no correlation between carbon dioxide and ammonia in all barns measured, but in cubicle barns the correlation was significant (Pearson coefficient $\mathrm{r}=0.60, \mathrm{p}<0.01$ ). Airborne exposure especially to gases was low in the one cold cubicle studied. However, there might be other factors, such as low temperatures, slipperiness and ergonomics in cold, which have an adverse effect on farmers.
The occupational exposure of farmers to gases and dusts in cubicle barns has been rarely reported previously in the literature. The results show that the exposure to several hazards is lower than in older, tied cow houses, but gas exposure have remained at the same level. The main reasons for the decrease are the automatic feeding systems for cows, the automatic ventilation systems and minor use of material containing organic dusts. Occupational respiratory diseases are, however, common among farmers and further research is needed to study the relationship between exposure and diseases. To improve the environmental conditions in the cow houses studied, emphasis should be placed on design of the buildings - especially the ventilation. Only one farm had a proper design for ventilation. Ventilation affects many environmental exposures, namely ammonia, carbon dioxide, temperature, relative humidity and to a small extent also dust. Another measure for improvement is provision of additional heat, which is needed in cow houses during wintertime. Warming the supply air increases the rate of ventilation and reduces air impurities and relative humidity. Although working conditions have become more comfortable and organic and biological exposures have decreased, there are still exposures that threaten farmers' health.

Acknowledgements. This study was supported by the grant from Farmers' Social Insurance Institution, Espoo, Finland. We wish to thank Ms. Minna Kallionpää, Mr. Heikki Kallunki and Mr. Kari Ojanen for their participation in data collection and Mr. Pentti Mäkelä for statistical advice.

\section{References}

CEN 1995. Workplace atmospheres - guidance for the assessment of exposure by inhalation to chemical agents for comparison with limit values and measurement strategy. EN 689. European Committee for Standardization, Brussels.

Dalphin, J.C., Pernet, D., Reboux, G., Martinez, J., Dubiez, A., Barale, T. \& Depierre, A. 1991. Influence of mode of storage and drying of fodder on thermophil- ic actinomycete aerocontamination in dairy farms of Doubs region of France. Thorax 46: 619-623.

Dix, N.J. \& Webster, J. 1995. Fungal Ecology. Chapman \& Hall, London. 549 p.

Donham, K.J. 1991. Association of environmental air contaminants with disease and productivity in swine. American Journal of Veterinary Research 52: 17231730. 


\title{
AGRICULTURAL AND FOOD SCIENCE IN FINLAND
}

\author{
Louhelainen, $K$. et al. Farmers' exposure to dusts and gases in cubicles
}

- 1993. Respiratory disease hazards to workers in livestock and poultry confinement structures. Seminars in Respiratory Medicine 14: 49-59.

- , Reynolds, S.J., Whitten, P., Merchant, J.A., Burmeister, L. \& Popendorf, W.J. 1995. Respiratory dysfunction in swine production facility workers: Doseresponse relationships of environmental exposures and pulmonary function. American Journal of Industrial Medicine 27: 405-418.

Gustafsson, G. 1988. Luft- och vărmebalanser i djurstallar (Air and heat balances in animal houses, in Swedish). Rapport 59, Sveriges Lantbruksuniversitet, Lund. $385 \mathrm{p}$.

Hanhela, R., Louhelainen, K. \& Pasanen, A.-L. 1995. Prevalence of microfungi in Finnish cow barns and some aspects of the occurrence of Wallemia sebi and Fusaria. Scandinavian Journal of Work Environment \& Health 21: 223-228.

Kangas, J., Louhelainen, K. \& Husman, K. 1987. Gaseous health hazards in livestock confinement buildings. Journal of Agricultural Science in Finland 59: 57-62.

Karjalainen, A., Aalto, L., Jolanki, R., Keskinen, H. \& Savela, A. 1997. Ammattitaudit 1996 (Occupational diseases 1996). Katsauksia 136, Terveys 1997:3, Työterveyslaitos, Helsinki.

- , Vasama, M., Savela, A., Jolanki, R. \& Kauppinen, T. 1996. Ammattitaudit 1995 (Occupational diseases 1995). Katsauksia 133, Terveys 1996:4, Työterveyslaitos, Helsinki.

Kauppinen, T., Vaaranen, V., Vasama, M., Toikkanen, J. \& Jolanki, R. 1994. Ammattitaudit 1993 (Occupational diseases 1993). Katsauksia 130, Työterveyslaitos, Helsinki.

-, 1995. Ammattitaudit 1994 (Occupational diseases 1994). Katsauksia 132, Työterveyslaitos, Helsinki.

Kotimaa, M. 1990. Spore exposure arising from stored hay, grain and straw. Journal of Agricultural Science in Finland 62: 285-291.

- , Husman, K., Terho, E.O. \& Mustonen, M.1984. Airborne molds and actinomycetes in the work environment of farmer's lung patients in Finland. Scandinavian Journal of Work Environment \& Health 10: 115119.

- , Oksanen, L. \& Koskela, P. 1991. Feeding and bedding material as sources of microbial exposure on dairy farms. Scandinavian Journal of Work Environment \& Health 17: 117-122.

- , Terho, E.O. \& Husman, K.1987. Airborne moulds and actinomycetes in the work environment of farmers. European Journal of Respiratory Diseases 71, Suppl 152: 91-100.

Laitinen, S., Kangas, J., Kotimaa, M., Liesivuori, J., Martikainen, P., Nevalainen, A., Sarantila, R. \& Husman, K. 1994. Worker's exposure to airborne bacteria and endotoxins at industrial wastewater treatment plants. American Industrial Hygiene Association Journal 55: 1055-1060.

Liesivuori, J., Kotimaa, M., Laitinen, S., Louhelainen, K., Pönni, J., Sarantila, R. \& Husman, K. 1994. Airborne endotoxin concentrations in different work conditions. American Journal of Industrial Medicine 25: 123-124.
Linnainmaa, M., Louhelainen, K. \& Eskelinen, T. 1993. Effect of ventilation on ammonia levels in cowhouses. American Industrial Hygiene Association Journal 54: 678-682.

Louhelainen, K., Kangas, J., Husman, K. \& Terho, E.O. 1987a. Total concentrations of dust in the air during farm work. European Journal of Respiratory Diseases 71, Suppl 152: 73-79.

-, Vilhunen, P., Kangas, J. \& Terho, E.O. 1987b. Dust exposure in piggeries. European Journal of Respiratory Diseases 71, Suppl 152: 80-90.

Malmberg, P.1990. Health effects of organic dust exposure in dairy farmers. American Journal of Industrial Medicine 17: 7-15.

- , Rask-Andersen, A. \& Rosenhall, L.1993. Exposure to microorganisms associated with allergic alveolitis and febrile reactions to mold dusts in farmers. Chest 103: 1202-09.

Olenchock, S.A., May, J.J., Pratt, D.S., Piacitelli, L.A. \& Parker, J.E. 1990. Presence of endotoxins in different agricultural environments. American Journal of Industrial Medicine 18: 279-284.

Palmgren, U., Ström, G., Blomqvist, G. \& Malmberg, P. 1986. Collection of airborne microorganisms on $\mathrm{Nu}$ clepore filters, estimation and analysis - CAMNEA method. Journal of Applied Bacteriology 61: 401-406.

Pasanen, A.-L., Kalliokoski, P., Pasanen, P., Salmi, T. \& Tossavainen, A. 1989. Fungi carried from farmers' work into farm homes. American Industrial Hygiene Association Journal 50: 631- 633.

SFS 3860 . Finnish standard on Measurement of dust concentration in workplace air with filter method. Finnish Standards Institution, 1988. (in Finnish-Swedish).

Tammilehto, L., Terho, E.O., Kurppa, K. \& Husman, K. 1994. Hengityselinsairaudet (respiratory diseases). In: Susitaival, P. (ed.). Työterveys ja maatalous Suomessa 1992. (Farming and occupational health in Finland in 1992, in Finnish with English summary). ML: 133, Social Insurance Institution, Helsinki. p. $91-100$.

Terho, E.O., Heinonen, O.P., Lammi, S. \& Laukkanen, V. 1987. Incidence of clinically confirmed farmer's lung in Finland and its relation to meteorological factors. European Journal of Respiratory Diseases 71, Suppl 152: 47-56.

Työministeriö 1996. HTP-arvot 1996. (Occupational Exposure Limits 1996, in Finnish). Työministeriö, Tampere. 8 p. + app.

Virtanen, T., Eskelinen, T., Husman, K. \& Măntyjărvi, R. 1992. Long- and short-term variability of airborne bovine epithelial antigen concentrations in cowsheds. International Archives of Allergy and Immunology 98: 252-255.

- , Louhelainen, K. \& Măntyjărvi, R. 1986. Enzymelinked immonosorbent assay (ELISA) inhibition method to estimate the level of airborne bovine epidermal antigen in cowsheds. International Archives of Allergy and Applied Immunology 81: 253-257.

- , Vilhunen, P., Husman, K., Happonen, P. \& Măntyjărvi, R.1988. Level of airborne bovine epithelial antigen in Finnish cowsheds. International Archives of Occupational and Environmental Health 60: 355-360. 
Vol. 6 (1997): 207-217.

Ylönen, J., Nuutinen, J., Rautiainen, M., Ruoppi, P., Mäntyjärvi, R. \& Virtanen, T. 1990. Comparative analysis of bovine extracts by immunoblotting and ELISA inhibition. Allergy 45: 30-39.
- , Virtanen, T., Rytkönen, M. \& Mäntyjärvi, R. 1994. Quantification of a major bovine allergen by a twosite immunometric assay based on monoclonal antibodies. Allergy 49: 707-712.

\title{
SELOSTUS
}

\section{Maanviljelijöiden altistuminen pölyille ja kaasuille nykyaikaisissa navetoissa}

\author{
Kyösti Louhelainen, Juhani Kangas, Marjut Reiman ja Pentti Kalliokoski \\ Kuopio aluetyöterveyslaitos ja Kuopion yliopisto
}

Tutkimuksessa selvitettiin viljelijöiden altistumista kaasuille ja pölyille nykyaikaisissa pihattonavetoissa. Tutkimuksessa oli mukana 23 pihattoa, yksi kylmäpihatto ja kaksi parsinavettaa. Navetoissa oli keskimäärin 22 lypsylehmää. Tutkittavat ilman epäpuhtaudet olivat kokonaispöly, lehmän karva- ja hilseallergeeni, mikrobit, endotoksiinit sekä kaasuista ammoniakki, hiilidioksidi ja rikkivety. Mittaukset tehtiin sisäruokintakaudella lehmien ruokinta- ja lypsytöiden aikana.

Tutkituissa navetoissa kokonaispölypitoisuudet olivat keskimäärin pieniä, alle $2 \mathrm{mg} / \mathrm{m}^{3}$, kun työsuojeluviranomaisten antama suositusarvo on $5 \mathrm{mg} / \mathrm{m}^{3}$. Tämä on mm. kehittyneiden työmenetelmien ansiota. Esimerkiksi automaattisten ruokintalaitteiden käyttö vähentää pölylle altistumista. Vähentynyt kuivaheinän käyttö vähentää ilman epäpuhtauksia ja vaikuttaa osaltaan myös kokonaispölypitoisuuteen. Rehun otto siilosta ja jakelu vasikoille oli syynä satunnaisiin suuriin pölypitoisuuksiin.

Lehmän karva- ja hilseallergeenipitoisuuksia on mitattu vähän navetoissa. Hilsepöly aiheuttaa viljelijöille vuosittain satoja ammattitauteja kuten nuhaa, astmaa ja ihottumia. Tutkimuksessa mitattiin kahta allergeenia, joiden pitoisuudet olivat erittäin pieniä kokonaispölymäärään verrattuna. Allergeenipölyä oli viljelijöiden hengitysvyöhykkeellä, ruokintapöydällä ja lypsyasemalla, joten viljelijä altistuu tälle pölylle kaikkialla navetassa.

Tutkimuksessa mitattiin viiden erityyppisen mikrobiryhmän pitoisuuksia. Kaikkien mikrobien pitoisuudet olivat pienempiä kuin aiemmissa suomalaisissa navetoissa tehdyissä tutkimuksissa. Ruokinnanaikainen homeitiöpitoisuus oli keskimäärin 4000-6000 itiötä $/ \mathrm{m}^{3}$, kun suurimmat pitoisuudet olivat noin $150000 \mathrm{itiötä/} / \mathrm{m}^{3}$. Mikrobien lähteinä olivat kuivaheinä, rehu ja olkikuivike. Endotoksiinia on tiettyjen bakteerien soluseinässä. Koska lehmätiloilla käytetään bakteereja sisältäviä materiaaleja, navetan ilmassa on myös endotoksiinia. Sen pitoisuutta on mitattu aiemmin vain yhdessä tutkimuksessa Suomessa. Kummassakin tutkimuksessa keskimääräinen pitoisuus oli suurin piirtein sama. Suurin yksittäinen pitoisuus oli erittäin suuri verrattuna suositeltuun raja-arvoon.

Ammoniakkipitoisuudet olivat pienimpiä suljetuilla lypsyasemilla. Ruokintakäytävältä mitatut pitoisuudet olivat yhtä suuria kuin vanhemmista navetoista mitatut. Nykyaikaisten navettojen keskimääräinen hiilidioksidipitoisuus ei ole pienentynyt vanhempiin tuotantorakennuksiin verrattuna. Rikkivetyä ei osoitettu mittauksissa.

Ilmanvaihto vaikuttaa mm. kaasupitoisuuksiin. Kaasupitoisuuksista voidaan päätellä, että ilmanvaihtojärjestelmät eivät olleet riittävän tehokkaita poistamaan kaasuja. Lisäksi navettojen suhteellinen kosteus oli keskimäärin yli $85 \%$. Tutkituista navetoista vain yhdessä oli yksityiskohtainen ilmanvaihtosuunnitelma.

Yhteenvetona voidaan todeta, että viljelijöiden altistuminen ilman epäpuhtauksille on vähäisempää uusissa navetoissa kuin vanhoissa parsinavetoissa. Kaasu- ja mikrobipitoisuudet olivat suljetuilla lypsyasemilla pienempiä kuin avonaisilla. Kuitenkin viljelijät altistuvat epäpuhtauksille satunnaisesti ja uudetkaan navetat eivät takaa viljelijöiden terveyttä. Tulevaisuudessa erityisesti ilmanvaihtoon tulee panostaa voimakkaasti navetoita suunniteltaessa. 